\title{
A Picture of Tuberculosis in Young Portuguese People in the Early 20th Century: A Multidisciplinary Study of the Skeletal and Historical Evidence
}

\author{
Ana Luísa Santos ${ }^{1 *}$ and Charlotte A. Roberts ${ }^{2}$ \\ ${ }^{1}$ Departamento de Antropologia, Universidade de Coimbra, 3000-056 Coimbra, Portugal \\ ${ }^{2}$ Department of Archaeology, University of Durham, Science Site, Durham DH1 3LE, UK
}

\begin{abstract}
KEY WORDS diagnosis; macroscopic; radiological; treatment; Coimbra Identified Skeletal
\end{abstract} Collection; Portugal; 20th century

\begin{abstract}
The aim of this study was to examine the evidence, and consider the differential diagnosis, for tuberculosis (TB) in juvenile individuals from early 20th century documented skeletons. There are 66 male and female juvenile individuals in the Coimbra Identified Skeletal Collection (CISC) with an age at death ranging from 7-21 years. The individuals died between 1904-1936 in different areas of Coimbra, Portugal. Eighteen of these individuals died from TB affecting different parts of the body. Thirteen $(72.2 \%)$ showed skeletal lesions that may be related to this infection. Of the 48 individuals with a non-tuberculous cause of death, only $2(4.2 \%)$ had skeletal changes that could be attributed to TB. The distribution of
\end{abstract}

Documentary evidence identifies tuberculosis (TB) (also called struma, scrofula, phthisis, consumption, lupus vulgaris, and Pott's disease) as a major cause of death and one of the most common pathological conditions plaguing past populations, especially for the post-medieval period in Europe. Following the 17th century, TB rose to epidemic proportions (Daniel, 1997). For example, in 1667, $20 \%$ of all deaths in London were due to TB (Myers, 1977). Another peak in frequency of TB occurred at the end of the 18th century with the Industrial Revolution, and at the beginning of the 19th century. At that time in the Hôpital de Charité in Paris, $36 \%$ of deaths were due to TB (Scannell, 1992). It was only after 1882, when Robert Koch identified Mycobacterium tuberculosis as the agent causing TB (Brock, 1982), that its diagnosis became more accurate, with the development of methods that permitted positive identification. However, assessing the reliability of past diagnoses documented in historical records is difficult because the clinical manifestations of TB are not pathognomonic of the disease and may be the result of other pulmonary diseases. With Koch's discovery, the development of preventive medicine for TB began. In 1921 the TB vaccine (Bacille CalmetteGuérin) was first tested on humans, and its general skeletal manifestations caused by the types of TB under study, based on macroscopic and radiological findings, is described and discussed. In addition, the medical records from 6 tuberculous individuals who died in Coimbra University Hospital (CUH) were analysed, and the information, including their diet and access to treatment, is presented. This work, based on data arising before antibiotics became available for treatment, can contribute to the future diagnosis of TB in non-documented skeletal material, and will facilitate a more reliable diagnosis of TB in juvenile individuals. Am J Phys Anthropol 115:38-49, 2001.

๑ 2001 Wiley-Liss, Inc.

use began in 1924 (Daniel, 1997). Besides this vaccine, and the development of drug therapy in the 1940s and later, improvement in living conditions and diet in the last few decades have contributed to diminishing the rate and severity of TB, certainly in developed countries.

In many European countries and North America, an earlier decrease of cases from the second half of the 19th century is recorded (Wood et al., 1992; Johnston, 1993). A factor that should be considered as a possible explanation for this decline, apart from improvements in the quality of life and developments in medicine, is "herd immunity," or the acquisition of immunity to TB by a human population recently devastated by the infection (Ávila, 1992; Daniel, 1997, p. 28). Despite this decline, since the late 1980s TB has again increased unexpectedly in

Grant sponsor: Prodep-Acção 5.2 Doctoral Program; Grant number: N11/96.

\footnotetext{
*Correspondence to: Ana Luísa Santos, Departamento de Antropologia, Universidade de Coimbra, 3000-056 Coimbra, Portugal. E-mail alsantos@ci.uc.pt
}

Received 5 August 1999; accepted 5 January 2001. 
many industrialised countries (Brown, 1992; Raviglione et al., 1995). Factors likely responsible for this increase include one or more of the following: depressed immune systems, reactivation/reinfection in older people (Seymour, 1992; Daniel, 1997; van Rie et al., 1999), malnourishment, homelessness, poor hygiene, unhealthy living conditions, infection with HIV, presence of AIDS, infection with multidrug-resistant strains of the mycobacteria, and specific categories of occupations, e.g., healthcare workers (Brown, 1992; Clever and LeGuyader, 1995; Anderson, 1999). These factors, or a combination of them, are now contributing to 8,000 deaths from TB per day worldwide. It is also estimated that one third of the world's population is affected by this disease at any one time (World Health Organization, 1999).

\section{THE PALEOPATHOLOGY OF TUBERCULOSIS}

Paleopathological macroscopic evidence of TB in human skeletons has been found worldwide, and occurs in Europe as far back as ca. 4000 BC. For example, in Italy a tuberculous adolescent was reported by Formicola et al. (1987), and Stirland and Waldron (1990) described the earliest case of TB in Britain (4th century AD). From the 7th or 8th century, another case was documented from Switzerland (Ulrich-Bochsler et al., 1982), with Pálfi et al. (1992) describing lumbosacral and hip TB from 8th century Hungary. Wars, famine, overcrowding, unclean surroundings, and the sharing of living accommodation with animals were common in later and postmedieval villages, towns, and cities, and TB infiltrated many European countries. In Portugal, the first description of a probable case of TB was made by Cunha (1994) in a skeleton exhumed from S. João de Almedina Church, in Coimbra. Another two medieval individuals also show lesions consistent with TB, one from Granja de Serrões, near Sintra (Santos and Cunha, 1997) and the other from Corroios (Lopes et al., 1999).

In Africa, the first evidence consistent with TB was described by Petrie and Quibell (1896) and by Derry (1938) in Egyptian and Nubian bodies dated to 3300 BC. In the Middle East, Ortner (1979) described a possibly tuberculous skeleton from the Early Bronze Age in Jordan, and in Japan, Suzuki (1985) reported TB in the skeleton of an Ainu female. In North and South America, skeletal evidence from a number of sites was reported by Buikstra (1999) ranging in date from the 4th millennium $\mathrm{BC}$ to the 1600s. Apart from skeletal evidence a number of cases of TB have also been diagnosed after examining skeletal and mummified material for ancient DNA of the Mycobacterium tuberculosis complex (Spigelman and Lemma, 1993; Salo et al., 1994; Taylor et al., 1996; Crubézy et al., 1998) and also mycolic acids (Gernaey et al., 1999).

\section{Skeletal diagnosis of tuberculosis}

Despite the number of cases of TB reported, it is puzzling that the historical records for this infection, particularly in Europe, do not correlate with the skeletal record. Although many individuals may die before skeletal modifications can take place (Wood et al., 1992), skeletal lesions may be misinterpreted because bone can react in a limited number of ways to different diseases. Experience in diagnosis is necessary because many possible differential diagnoses are possible for lesions observed. It is worth noting that it is difficult to evaluate skeletal manifestations caused by mycobacterial infection before the development of antibiotics. In the past, skeletal change may have been different from manifestations seen today, and modern clinical diagnostic criteria for TB may be inadequate for paleopathological studies.

These concerns notwithstanding, based on clinical data, skeletal involvement in TB is very low. For extrapulmonary $\mathrm{TB}$, the rates for all osseous changes range from 1\% (Farer et al., 1979) to 9\% (Hopewell, 1994). Most of the identification of TB in past populations is based on the vertebral column, which is affected in 25-70\% of cases of skeletal TB (Resnick and Niwayama, 1988), and the weightbearing joints such as the hip and knee, these being the next most commonly affected (Roberts et al., 1998; Rogers and Waldron, 1995). Recently the clinical literature recorded modifications to thoracic cavity bony structures that are possibly induced by TB. Eyler et al. (1996: 925) reported that "the most common condition associated with rib enlargement was pulmonary TB" in a living population sample. Though any bone of the body has the potential to be affected by TB, other parts of the skeleton have only recently been considered as possible indicators of pulmonary disease, which may be TB (summarized in Roberts, 1999).

A useful source of information on how disease affects the skeleton is found in skeletal collections for which the causes of death are recorded. The first collection used to determine diagnostic features of TB was that of Hamann-Todd, housed in the Cleveland Museum of Natural History (Cleveland, $\mathrm{OH}$ ) (Kelley and El-Najjar, 1980; El-Najjar, 1981; Kelley and Micozzi, 1984). Subsequently, work on the Terry Collection curated by the National Museum of Natural History (Smithsonian Institution, Washington, DC) was undertaken (Roberts et al., 1994). Despite questions about the accuracy of the documented causes of death in these North American collections dated to the onset of the 20th century, rib lesions, such as new bone formation, were postulated as being the result of pulmonary infection, and more specifically of TB.

This study seeks to extend our knowledge of the diagnosis of TB in skeletal material. It focuses on documenting the evidence for TB in juveniles from the Coimbra Identified Skeletal Collection (CISC) in Portugal, and on correlating the skeletal findings 
with cause of death data. In particular, this research considers the validity of diagnostic criteria for TB taken from clinical sources.

\section{MATERIALS AND METHODS}

\section{The sample}

The current work is part of a major project on TB that is being developed with the CISC data: collating historical, macroscopic, radiological, and biomolecular evidence for TB in the individuals from the Collection. The Collection was accumulated in the first half of the 20th century (Rocha, 1995) and is curated in the Anthropological Museum at the University of Coimbra,. For each of the 505 individuals in the Collection, a record exists with information such as birth and death place, occupation, own and parents' names, and cause of death (Rocha, 1995; Santos, 1995a,b). The individuals died between 1904-1936, i.e., before the antibiotic era. Almost all the skeletons are complete and in a good state of preservation, although some periosteal destruction has occurred. Sex estimation (Cunha and van Vark, 1991; Silva, 1995), adult age-at-death estimation (Santos, 1995c, 1996), and paleopathological analysis (Cunha, 1993, 1995; Cunha and Gomes, 1994; Cunha and Umbelino, 1995) have been undertaken. Previous research on records at the Coimbra University Hospital (CUH), the place of death for 240 individuals, the Cemetery da Conchada (the place of burial for all the individuals), and autopsy documents of the Instituto de Medicina Legal, among others, provided important data that confirmed and complemented the Collection files, particularly concerning the causes of death (Santos, 1999).

The individuals examined consisted of 30 males and 36 females, mostly juveniles. This group of individuals was selected for study because juveniles are the age group most affected in past populations, though little information is available concerning the diagnosis of juvenile TB in past populations. The sample included 19 children (7-12 years old), 27 adolescents (12-20 years old), and 20 young adults (20-21 years old). The determination of these age groups was based on Buikstra and Ubelaker (1994). The individuals were born between 1887-1921 and died between 1904-1936. Coimbra was the place of death for all individuals: 5 died in the Military Hospital, 29 in different places in the town, and 32 at CUH. Determination of their socioeconomic status and occupation was possible from hospital entrance records. The patients were classified as first, second, and third class "pensioners," and the poor, with the first two groups paying for their own stay in hospital (Universidade de Coimbra, Direcção dos Hospitais, 1936). Only one juvenile was classified as second class, and 8 were categorized as third class, with 17 as poor. For the remaining 6 individuals, no socioeconomic status was recorded.

Concerning occupation, 19 individuals (14 females and 5 males) aged less than 12 years had no job recorded, and one 16-year-old boy was a student.
$\mathbf{N}$

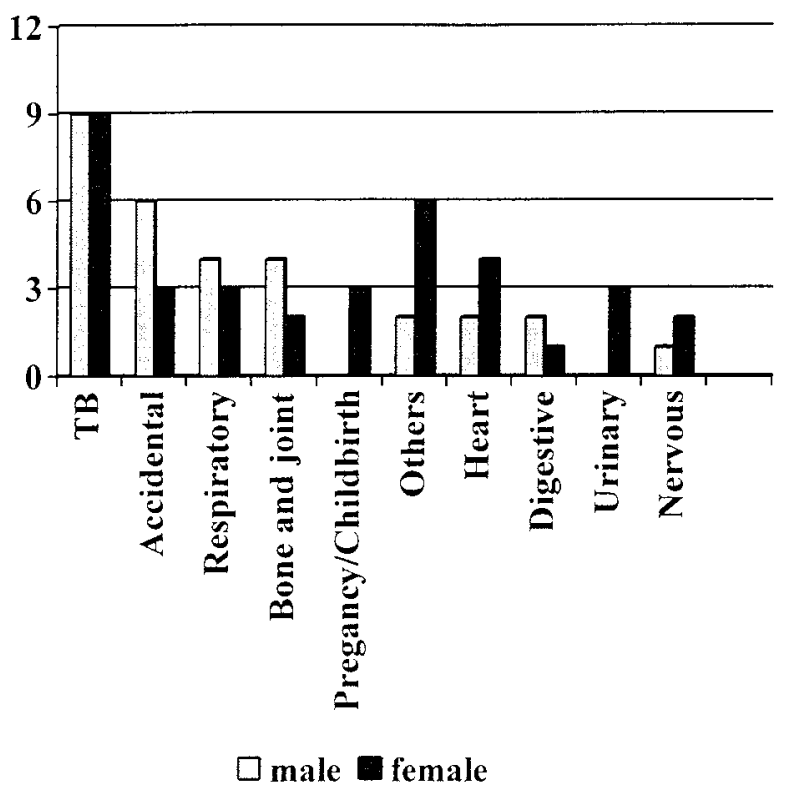

Fig. 1. Cause of death distribution of the sample, following WHO classification.

Three females were seamstresses, one was a daylaborer, and the remaining 18 did housework as housemaids and housewives. For males more occupations are recorded: 8 were "workers," and there were 7 soldiers, 2 employees in commerce, a locksmith, a pharmacy helper, a pastry-worker, an agricultural worker, a blacksmith, a tinsmith, and a primary school teacher. Marital status was also shown: only 4 females were married (2 aged 17 years, 1 aged 19, and 1 aged 20), and 2 single women (aged 21) died during pregnancy or childbirth.

All cause of death information was coded following WHO classification (Organização Mundial de Saúde, 1989). As was common in Portugal earlier in the 20th century, TB was the main cause of death (Fig. 1 ), and was responsible for 18 deaths (27.3\%) in this sample, followed by accidents (which included suicide and homicide), and in third place, respiratory problems (7 deaths). Table 1 displays the number of individuals with TB and pulmonary diseases specified as the causes of death in the Collection files. It must be noted that even though the stated cause of death may not have been TB, individuals could still have been infected, but death was attributed to another health problem.

\section{The analysis}

Each bone from the 66 individuals was observed macroscopically, without knowledge of cause of death. A detailed written and pictorial description of all bone changes from normal was made. Subsequently, radiographs were taken of all tuberculous vertebral columns and also for two other individuals, with "chronic bronchitis" and "osteoarthritis and septicemia" listed as causes of death. Several ribs, scapulae, and long bones with visible bone changes 
TABLE 1. Number of individuals by type of tuberculosis and nontuberculous respiratory disease recorded as a cause of death

\begin{tabular}{lrlr}
\hline \multicolumn{1}{c}{ Tuberculosis } & $\mathrm{N}$ & Respiratory disease & $\mathrm{N}$ \\
\hline Pulmonary & 8 & Bronchopneumonia & 2 \\
Pulmonary (bilateral) & 2 & Chronic bronchitis & 1 \\
Pulmonary and heart & 1 & Pleurisy & 1 \\
$\quad$ attack & 3 & "Flu pneumonia" & 1 \\
$\begin{array}{l}\text { Meningeal } \\
\text { Bone and joint }\end{array}$ & 1 & $\begin{array}{c}\text { "Double lobar" pneumonia } \\
\text { (Pneumococcus) }\end{array}$ & 1 \\
Enteric & 1 & $\begin{array}{c}\text { Bronchopneumonia and } \\
\text { tumor of the thyroid }\end{array}$ & 1 \\
& & gland & \\
Peritoneal & 1 & & 7 \\
Pulmonary & 1 & & \\
$\quad$ congestion & 18 & Total & \\
Total & & &
\end{tabular}

TABLE 2. Presence of periostitis on long bones and ribs in individuals with and without $T B$

\begin{tabular}{lrrrrrr}
\hline & & \multicolumn{2}{c}{ Long bones } & & \multicolumn{2}{c}{ Ribs } \\
\cline { 3 - 4 } \cline { 6 - 7 } \multicolumn{1}{c}{ Group } & $\mathrm{N}$ & $\mathrm{N}$ & $\%$ & & $\mathrm{~N}$ & $\%$ \\
\hline Pulmonary TB & 11 & 5 & 45.5 & & 10 & 90.9 \\
Other forms of TB & 7 & 3 & 42.9 & & 1 & 14.3 \\
Subtotal TB & 18 & 8 & 44.4 & & 11 & 61.1 \\
Pulmonary non-TB & 7 & 2 & 28.6 & & 1 & 14.3 \\
Others & 41 & 4 & 9.8 & & 1 & 2.4 \\
Subtotal non-TB & 48 & 6 & 12.5 & & 2 & 4.2 \\
Total & 66 & 14 & 21.2 & & 13 & 19.7 \\
\hline
\end{tabular}

were also radiographed, using the facilities in CUH. The radiography equipment used varied depending on availability of machines, and the bone being analyzed.

Chi-square testing of the data to determine significant associations (if any) was undertaken using the SPSS and Actus programs. The 66 were divided in two main groups related to their recorded cause of death: tuberculous and nontuberculous (Table 2). Furthermore, each group was subdivided into those who had pulmonary and extrapulmonary disease given as causes of death.

\section{RESULTS}

\section{Tuberculous causes of death}

Frequency of rib and long bone involvement. Periosteal reaction on long bones and new bone formation on the visceral surface of the ribs were both more frequent in tuberculous individuals. From a total of 66 individuals, $14(21.2 \%)$ had periosteal reaction on the long bones, and 13 (19.7\%) showed new bone formation on ribs (chi-square $=9.757, P<$ $0.005)$. Eight (44.4\%) of 18 individuals with TB as a cause of death, and 6 of 48 individuals (12.5\%) with a nontubercular cause of death (chi-square $=7.993$, $P<0.005$ ), had a periosteal reaction on their long bones. When the data were divided into four groups (Table 2), the association of periosteal reaction on ribs and long bones was statistically significant (chisquare $=9.277, P<0.05)$. When the four groups were compared (chi-square $=47.386, P<0.000$ ),

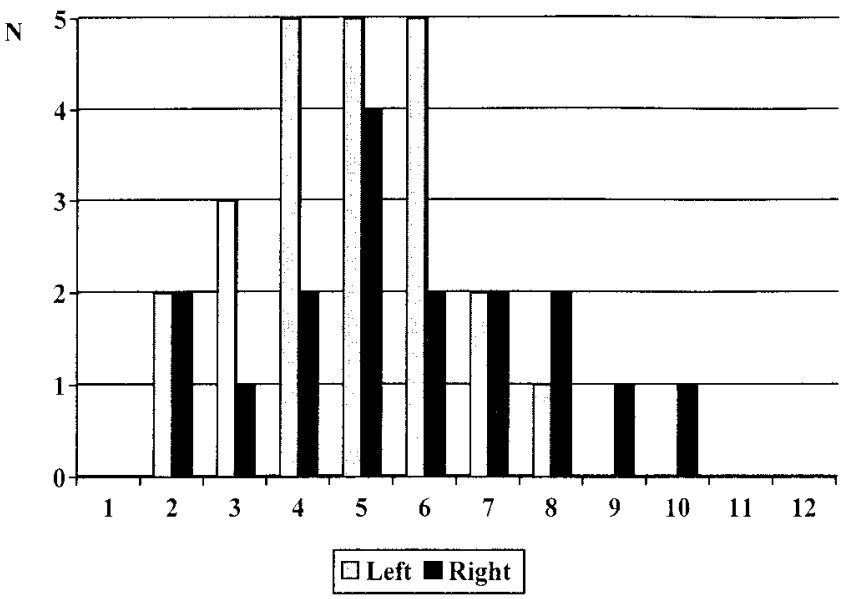

Fig. 2. Distribution of lesions for each of the 12 ribs: side and number of ribs affected in pulmonary TB individuals.

after the division had been made between tuberculous and nontuberculous individuals (chi-square $=$ 28.185, $P<0.001$ ), and when pulmonary TB and nonpulmonary TB causes of death were considered, there was a statistically significant difference between tuberculous and nontuberculous individuals, and between pulmonary TB and nonpulmonary TB causes of death.

Number and side of ribs involved. In the individuals with pulmonary TB as a cause of death, the number of ribs involved varied from 1-7, with 4 being most common. Of the 11 individuals dying from pulmonary TB, 10 (90.9\%) showed new bone formation on the visceral surface of ribs. In the 259 ribs from 11 individuals who died of pulmonary TB, $40(15.4 \%)$ showed new bone formation. In $17.7 \%$ (23/130), new bone occurred on the left side, and in $13.2 \%(17 / 129)$, on the right side (chi-square = $0.806, P=0.369)$. Figure 2 shows that none of the first, eleventh, and twelfth ribs showed new bone formation. The more common location of new bone is on ribs 4-6, and these lesions were very often more severe on ribs 5 and 6 . The location of the new bone along the rib occurred mainly on the vertebral ends, and new bone formed can be described as integral to the periosteum, or as an addition to the periosteal layer.

The new bone formation on ribs from people who had died with chronic bronchitis appeared more porous and less remodelled, but this may be the result of more recent new bone formation with no remodelling.

Hypertrophic osteoarthropathy. Among the pulmonary TB cases one individual, a seamstress aged 21 who died in 1932, is described in more detail since she presents extensive bone changes compatible with hypertrophic osteoarthropathy (Aufderheide and Rodríguez-Martin, 1998). The periosteal reaction was generalized to most of the skeleton: the right scapula, both humeri, radii (Fig. 3), and the 


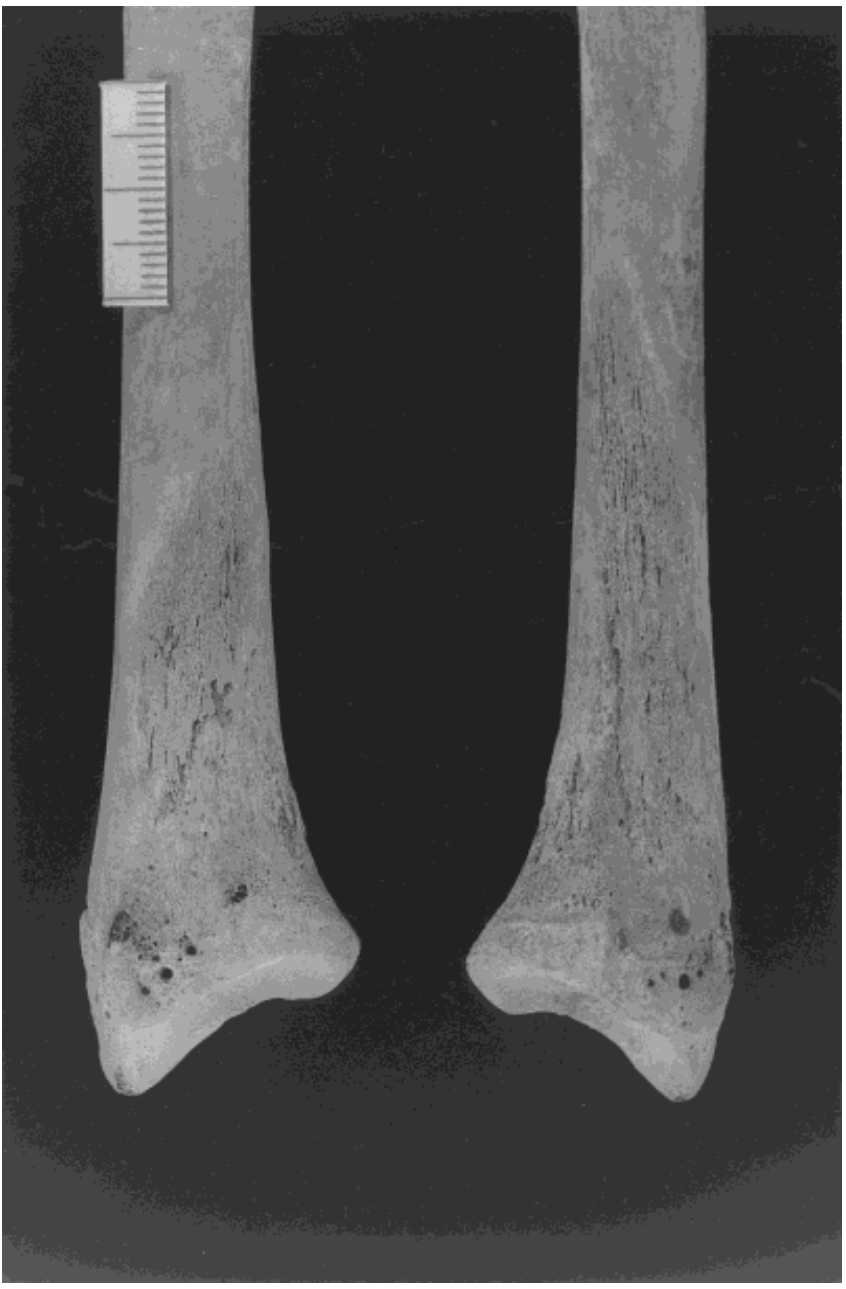

Fig. 3. Anterior view of inferior midshaft and distal ends of both radii, illustrating periosteal reaction (skeleton no. 429).

ulnae, femora (Fig. 4), fibulae, and foot bones revealed woven bone that was in the process of remodelling to lamellar bone. The twelfth pair of ribs was missing, but five others (Fig. 5) were affected on their vertebral ends (left side from 3-6, and the fifth on the right). On the endocranial surface new bone also occurred from the middle of the sagittal suture to the inion region. Radiographs were taken of several ribs, the vertebral column, scapulae, and long bones of both upper and lower limbs of this individual. Only in bones with extensive new bone formation, such as in the femur and metatarsal (Fig. 6), did the radiographs show periosteal thickening. Overall, the lesions could be better described without radiographic analyses.

Meningeal tuberculosis. The second most common type of TB as a cause of death in these juveniles was meningeal TB. A 7-year-old boy displayed subtle periosteal reaction on both ulnae and on the right tibia. This reaction is invisible on the radiograph. A 12-year-old female who died from meningeal TB had no signs of disease on her skeleton, and a third

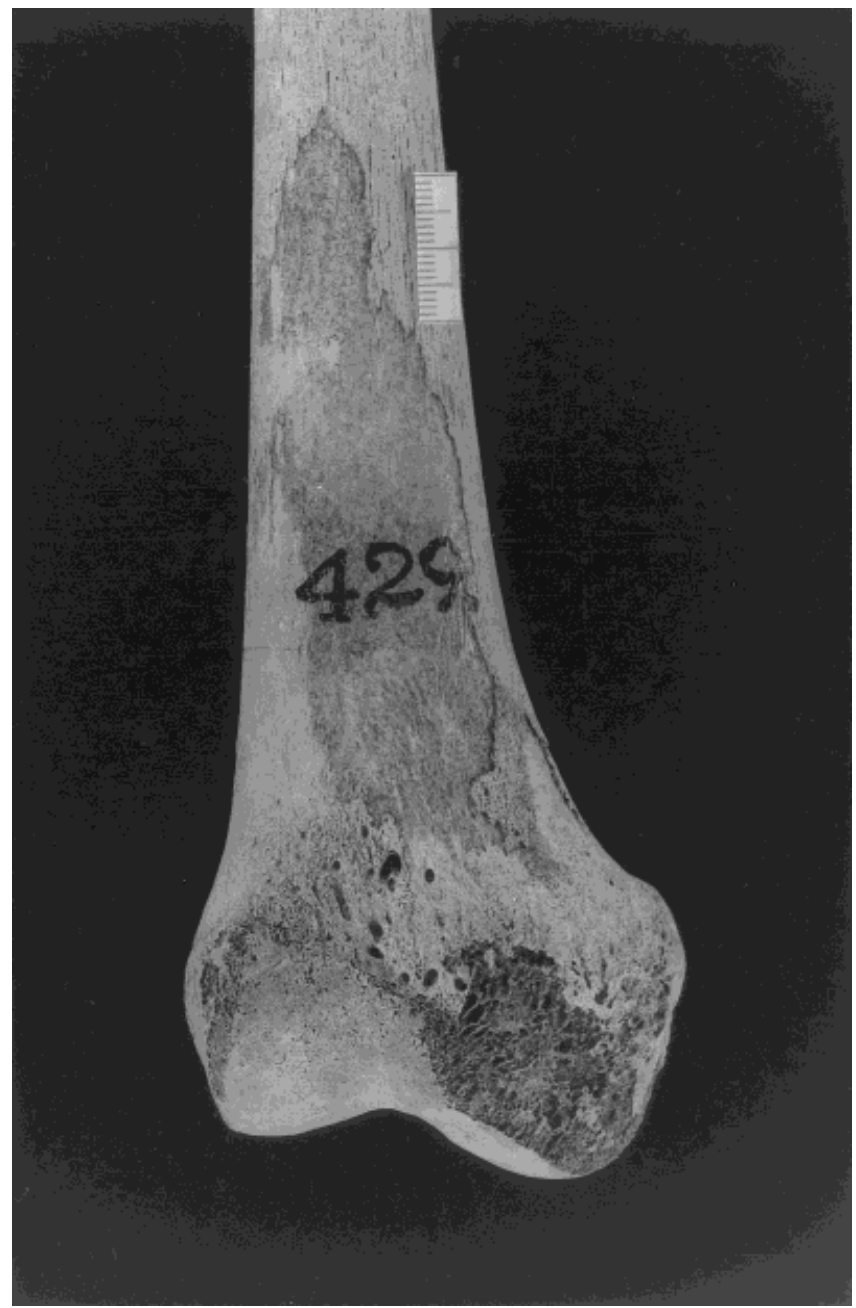

Fig. 4. Anterior view of inferior midshaft and distal end of femur, displaying periosteal reaction (skeleton no. 429).

person, a 16-year-old boy, exhibited changes of infection in the right femur (Fig. 7).

Other forms of tuberculosis. The remaining types of extrapulmonary TB represented in 4 individuals were osteoarticular, enteric, peritoneal, and pulmonary congestion/nonspecific tuberculosis. Bone, joint, and pulmonary TB occurred in a 10year-old girl. The infection was visible in the bones of the leg, being most evident at the proximal end of the left tibia. Bones from the affected side were very fragile and light when compared with those from the opposite side, possibly suggesting disuse atrophy due to nonweight-bearing on the affected limb for a long period of time. The fibula was also affected at both ends, with new bone formation. The radiograph only confirmed the macroscopic observations and the osteoporotic nature of the cancellous bone of the affected side. Finally, features on the calcaneus, where extensive bone reaction was noted with small spicules of new bone formation, were difficult to visualize on the radiographs.

The only vertebral column with bone change was associated with a 16-year-old boy with enteric TB 


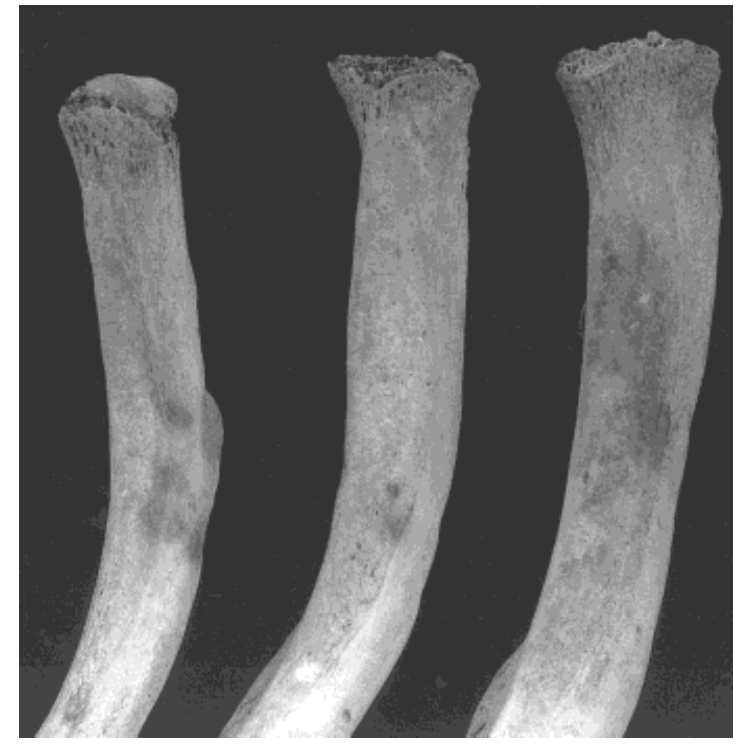

Fig. 5. Proliferation of new bone on visceral surface of several ribs from an individual who died from pulmonary TB (skeleton no. 429).

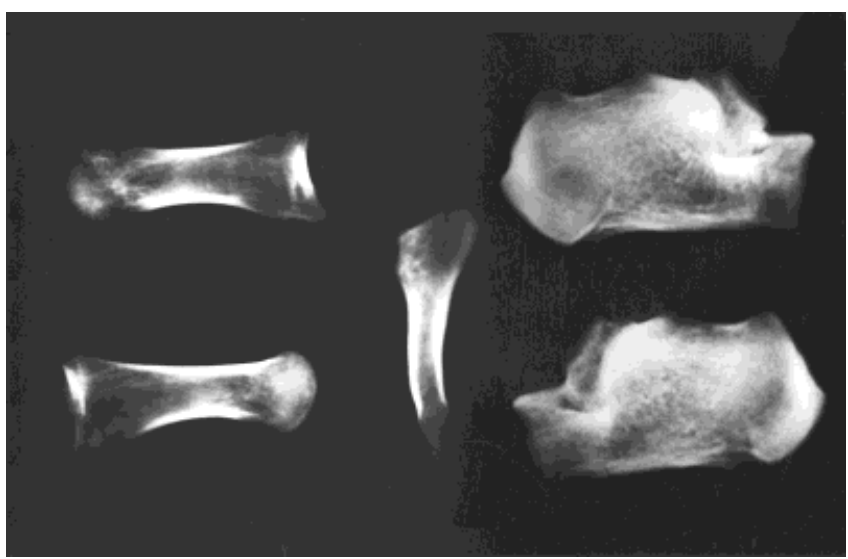

Fig. 6. Radiographs of a metatarsal and calcaneus, showing thickening and marked periosteal reaction (Siregraphic C Siemens, standard distance focus film, film universal yellow $30 \times 40$, $40 \mathrm{KV}, 5-\mathrm{mA}$ seconds) (skeleton no. 429).

(Fig. 8). The destruction starts on $\mathrm{C} 7$ and increases in severity until there is complete destruction of the vertebral body of $\mathrm{T} 7$ and posterior fusion of $\mathrm{T} 7$ and T8 (Fig. 9).

In the peritoneal TB case, affecting a female houseworker 19 years of age, rib lesions were also present. However, some differences were found when comparing these changes with those resulting from pulmonary TB. In the nonpulmonary case, the lower ribs were affected on both sides of the thoracic cage. On the left side, these lesions occupied most of the extent of the ribs, from $2-11$; there was more extensive and severe changes on the tenth rib on the left side. Here, the new bone covered almost all the breadth of the rib in three areas (7-10 $\mathrm{mm}$ superoinferiorly): $21 \mathrm{~mm}$ in length on the vertebral end, 27 $\mathrm{mm}$ on the midshaft, and $23 \mathrm{~mm}$ on the sternal end of the rib. This discontinuity can be related to post-

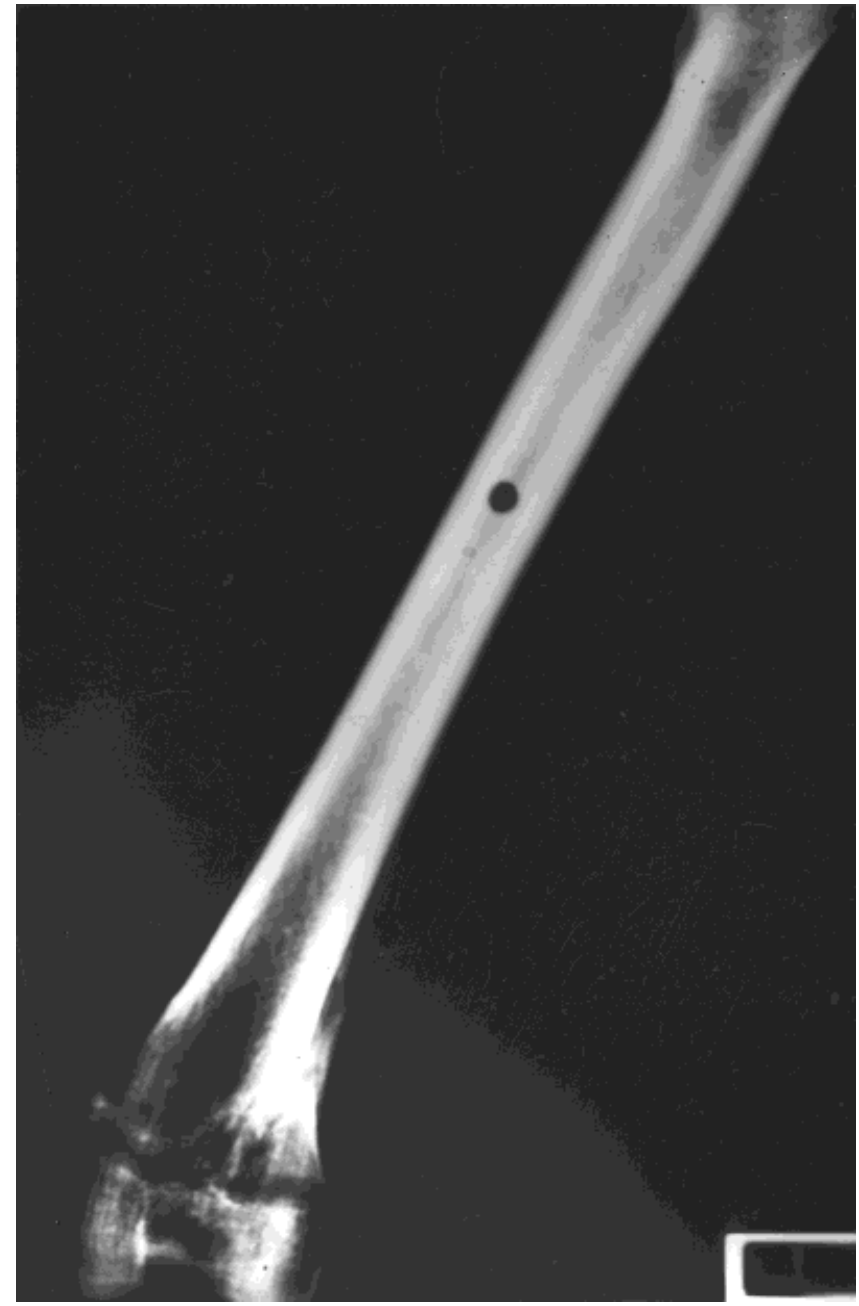

Fig. 7. Radiograph of right femur in which the inferior epiphysis has incomplete fusion. A layer of incompletely calcified new bone formation on the lateral side of the distal quarter of the shaft covers what appears to be a nonhealed fracture (Esamatic 750, standard distance focus film, film universal yellow $30 \times 40,46$ KV, 32-mA seconds) (skeleton no. 412).

mortem damage on the rib. On the right side, the lesions appeared only on ribs 10 and 11, and were around $5 \mathrm{~cm}$ in length. Contrary to what occurred in the ribs of pulmonary TB individuals, where the new bone tends to appear on the vertebral ends, here the lesions were more common on sternal ends. Some ribs with new bone formation were radiographed and, even without skin, muscles, and lungs, it was impossible to see these bone changes, especially antero-posteriorally. No lesions were observed in a 10year-old girl with a cause of death listed as pulmonary congestion/nonspecific tuberculosis.

\section{Nontuberculous causes of death}

For the nontuberculous cases, only $4.2 \%$ (2/48) showed rib lesions (Table 2). These were 2 males, both 19 years of age at the time of their deaths. One was a pastry-worker who died from chronic bronchitis, and the other was a "worker" who was admitted to hospital due to osteoarthritis and septicemia. The 

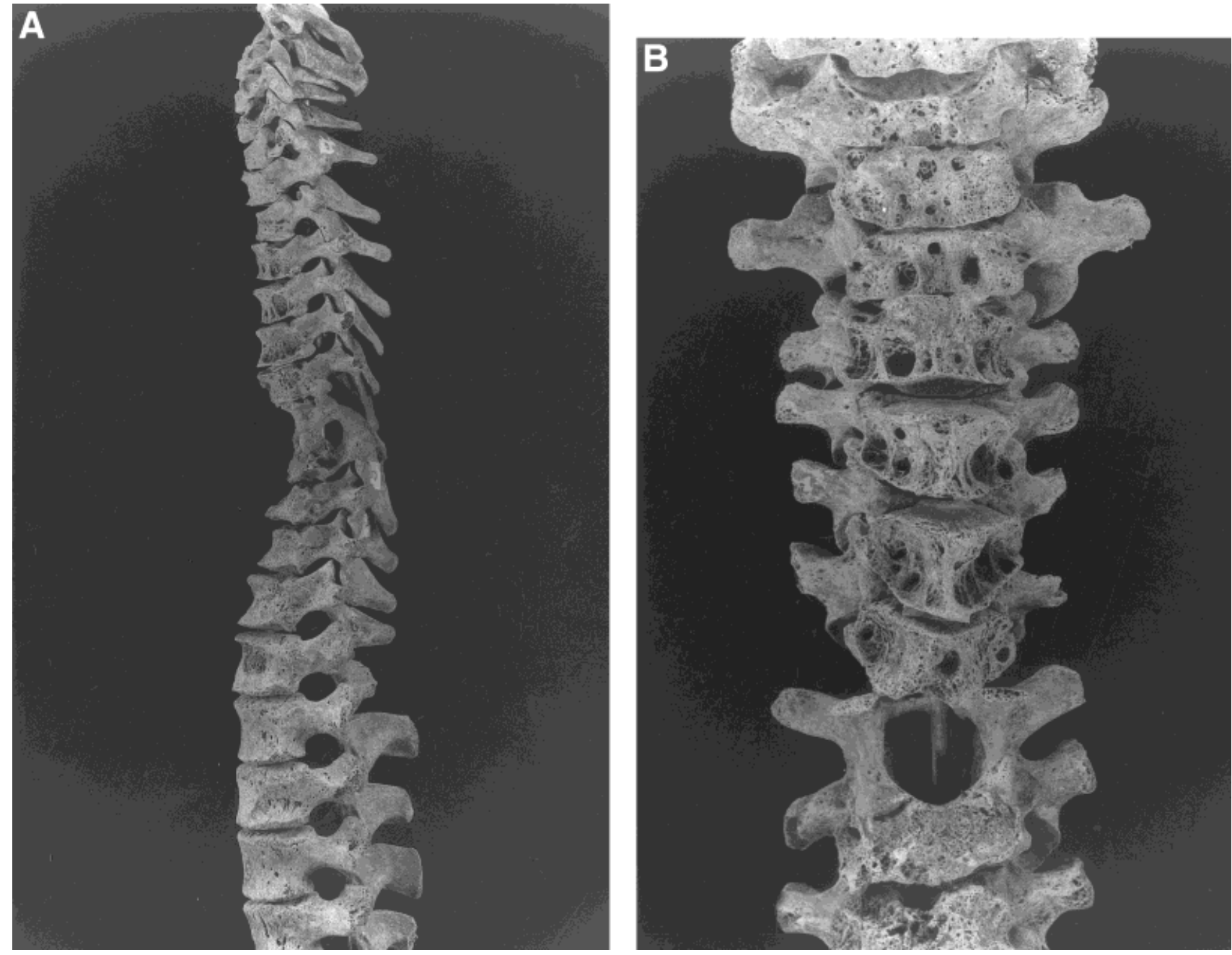

Fig. 8. Spine of a 16-year-old boy, showing destruction of several vertebral bodies. Frontal (A) and lateral (B) view of spine (skeleton no. 6).

first individual had slight new bone formation on the inion region on the endocranial surface of the skull, on both scapulae (Fig. 10), humeri, radii, right ulna, and left tibia. Additionally, the left (second to sixth, and more severe on the fourth) and right (2-7) ribs also presented new bone formation (Fig. 11), with a smooth remodelled appearance. Radiographs were taken of the scapulae, vertebral column, and several ribs of this individual, but no further information was acquired.

Osteoarthritis of the right knee and septicemia were the diseases recorded on the other patient's file and mentioned as a cause of death. This individual had periosteal reaction on the right femur, patella, and tibia; on the radiographs, some changes of the periosteal surface could be seen. The distal femoral joint surface was almost totally destroyed, and lamellar bone formation was seen in the lateral distal third of the shaft. Because postmortem damage was also present, it is impossible to know if the femur was fused to the tibia. New bone formation occurred on the vertebral ends of the left ribs (4-10), and on the right side (2-11), being more severe on the ninth. In this individ- ual the vertebral end location and the texture of the lesions are similar to the changes found in individuals who died from pulmonary TB. However, in the previous individual, apart from the different texture, the new bone extends along the whole of the rib or is located at its sternal end.

Of the remaining 4 individuals with periosteal reaction and a nontuberculous cause of death, one died with osteomyelitis of the left femur. The other 3 people died from the following causes of death: heart, respiratory, and digestive disease.

\section{DISCUSSION}

\section{Tuberculosis in juveniles}

Current data from European countries and North America state that the incidence of, and mortality from, TB among juveniles is very low (Rieder et al., 1989). Nevertheless, the historical literature suggests that in this age group, TB was common (Porto, 1927). The profile of TB mortality seems to have changed during the 20th century. In 1929 the Instituto Nacional de Estatística recorded in Portugal 

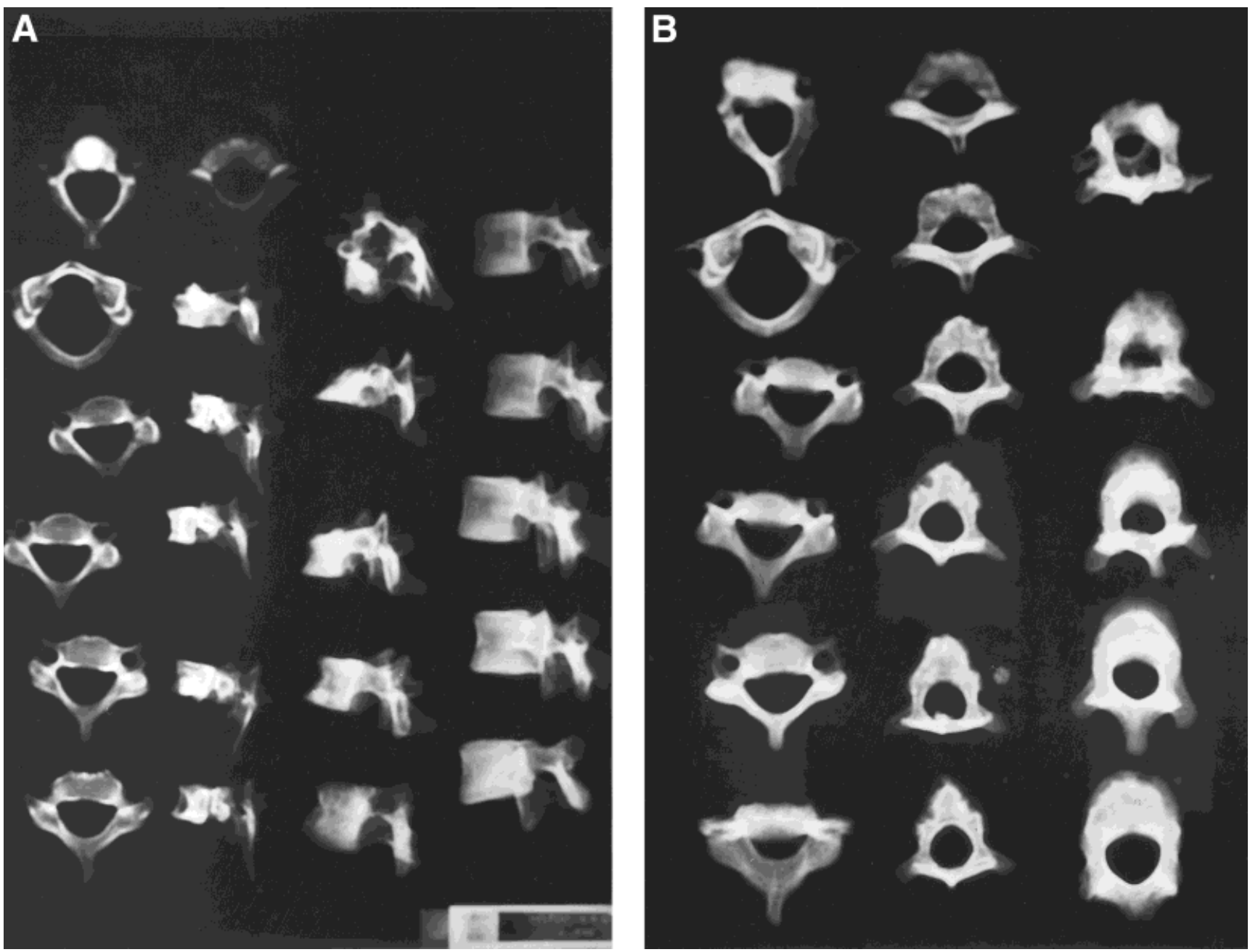

Fig. 9. Radiograph of several vertebral bodies partially or completely destroyed by infection: lateral (A) and super-inferior (B) views of spine (Siregraphic C Siemens, standard distance focus film, film universal yellow $30 \times 40,40 \mathrm{KV}$, 3,2-mA seconds) (skeleton no. 6).

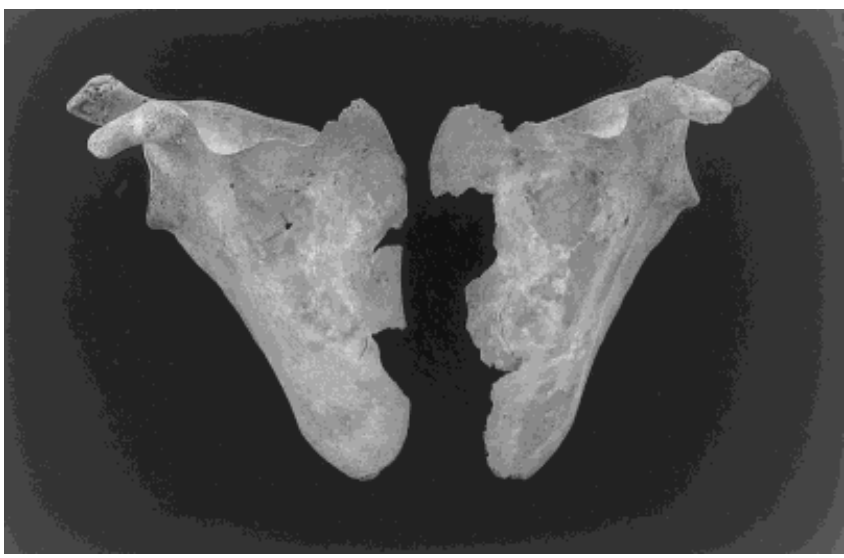

Fig. 10. Both scapulae display new bone formation on the facies costalis and fossa supraspinata (skeleton no. 102).

that enteritis and diarrhea were the most common causes of death, followed by TB in children aged less then 2 years of age (Cutileiro, 1954). A maximum rate of deaths due to TB occurred in 1930 (around 200 deaths per 1,000,000 inhabitants), which corre- sponds to $10 \%$ of all deaths (Cutileiro, 1954; Gonçalves-Ferreira, 1990). In 1995, the Institute reported 234 deaths from TB (3.16/100,000), and 125 people (1.26/100,000 inhabitants) died later of the effects of this disease. The age group most affected was of individuals over 75, with 67 deaths (12.5/ $100,000)$ in childhood and only 2 individuals aged less than 14 dying of TB $(0.11 / 100,000)$ (Antunes and Antunes, 1997). At the beginning of the 20th century, Coimbra displayed low rates of TB in comparison to other Portuguese cities and towns. Porto (1927) estimated from 1910-1920 an annual mean mortality due to TB of 69 individuals (24.5 per 10,000 inhabitants), for the 28,104 inhabitants. However, it is difficult to evaluate the reliability of cause of death data and make statistical comparisons (Bryder, 1996).

\section{Identification of tuberculosis in skeletal material}

In spite of pulmonary TB being the most common type of the infection in the past, its positive identi- 


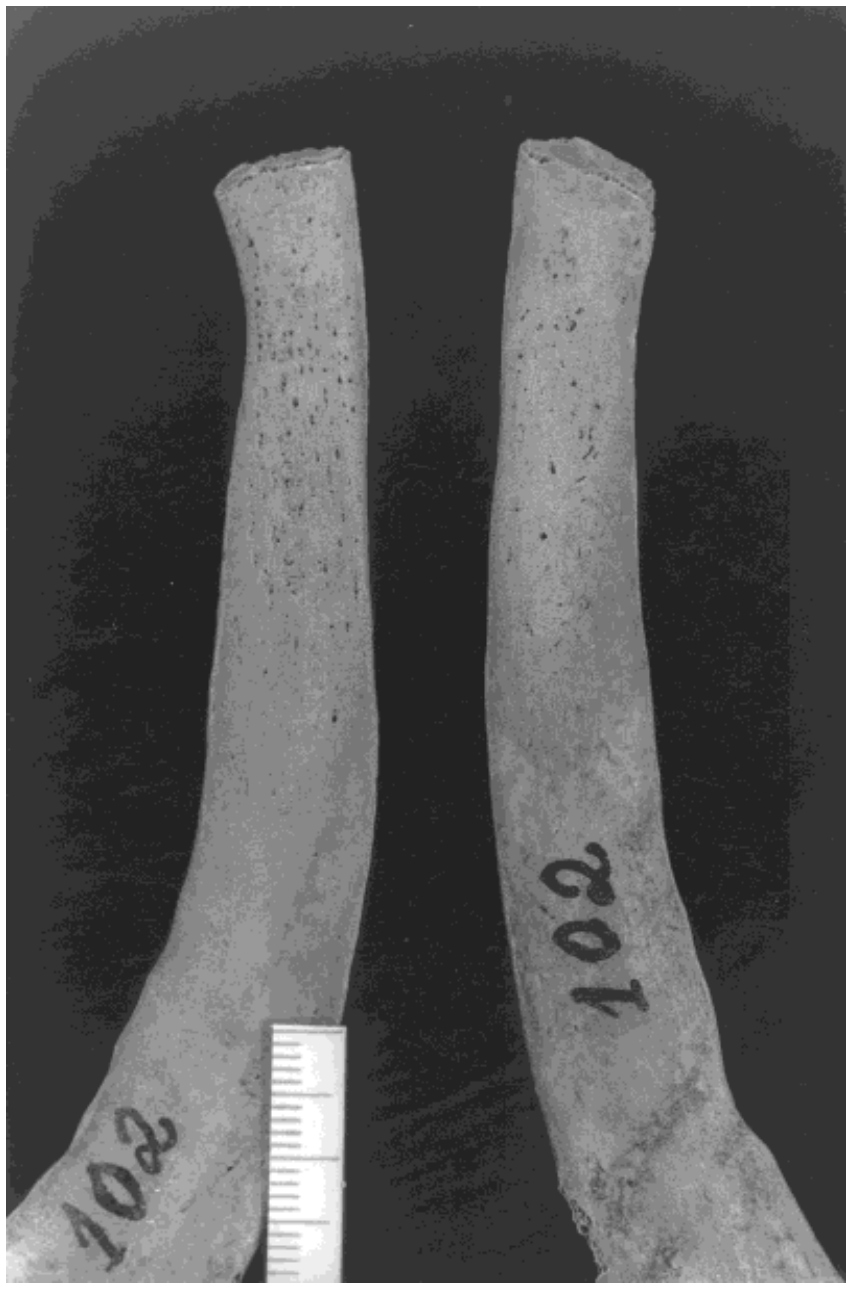

Fig. 11. New bone formation on the visceral surface of second ribs, extending from sternal end to midshaft (skeleton no. 102).

fication in human skeletons is rare, even though it is assumed that most people in the past probably acquired TB via the pulmonary route. Clinical diagnostic criteria used by paleopathologists rely on Pott's disease of the spine and less often on changes in the hip and knee joints. These criteria do not mention subtle bone lesions commonly seen on ribs and other bones of the skeleton in archaeological populations, which may be related to TB. When diagnosing TB today, physicians generally utilize sputum analysis and chest radiographs and do not commonly consider bone changes in their diagnosis. Therefore, it is not surprising that subtle bone damage which may be associated with TB (especially on the ribs) is not described as a diagnostic criterion. Furthermore, autopsies do not investigate the surface of ribs even when pleural adhesions are present. In other words, while physicians do not need to observe ribs for pulmonary TB diagnosis, these are potentially important elements for diagnosis of this disease in past populations. As shown in this study, subtle new bone formation was impossible to visualize on rib radiographs in the normal anatomical position for radiographs of the chest.
Very thick layers of new bone on rib surfaces, however, may be seen as cortical thickening on a superoinferior radiographic view of a rib.

Future investigations on skeletons in which the cause of death is recorded may clarify problems. However, caution is necessary because the disease recorded as the cause of death may not have been the only disease present in that person, and these unrecorded ailments may have contributed to an individual's demise. In our study sample, $56.1 \%$ (37/ 66) of individuals died in hospitals in Coimbra, which may give more confidence to the disease recorded as causing death, if we assume that diagnosis in a hospital was more accurate. Certainly other diseases were also recorded on the patient files of the CUH (Santos, 1999). The analysis of these documents reveals that for the 6 tuberculous juveniles, only 1 individual was diagnosed with osteoarticular and pulmonary TB, and for the others the disease recorded was simultaneously the cause of death. Nevertheless, caution must continue, as other conditions (e.g., treponemal disease) could have led to the long bone changes, although the patterning of bone changes was not consistent with this or any other disease.

The main findings in this study were as follows. New bone formation on long bones and ribs was significantly more common in individuals who had died from TB than in individuals who had died from a nontuberculous cause. For those who had died from pulmonary TB, the number of ribs involved varied from 1-7, with 4 being most common. In individuals who had died from pulmonary TB, 10 had new bone formation on ribs (90.9\%), and only 2 of 48 who had not died from TB $(4.2 \%)$ had lesions. In these cases the left side was more affected than the right, and the fourth to sixth ribs were most involved. The bone formation was mainly seen on the vertebral ends and was woven in nature in the majority of cases. Finally, it is noted that radiographic analysis did not provide any additional information that could not be seen macroscopically.

\section{Other work on rib lesions}

In the $1980 \mathrm{~s}$, research on the Hamann-Todd collection (Table 3) revealed that new bone formation on ribs was more frequent in tuberculous individuals (8.8\%). From the 352 pulmonary TB cases, 31 had lesions on the visceral surfaces of their ribs (Kelley and Micozzi, 1984). In the Terry collection, a stronger connection was found between pulmonary TB and rib lesions. Roberts et al. (1994) analyzed 1,718 individuals from the Terry Collection, and found rib lesions more common in individuals who had died from pulmonary TB (61.6\% or 157 of 255) than in individuals with a nontuberculous pulmonary cause of death $(22.2 \%$ or 51 of 230$)$. The difference between the results in the three identified collections (Table 3) may be the effect of the reliability of the cause of death recorded. However, a person could have rib lesions as a result of TB, even though 
TABLE 3. Comparison of number of individuals with new bone formation on ribs by types of disease considered for the three identified skeletal collections ${ }^{1}$

\begin{tabular}{|c|c|c|c|c|c|c|c|c|c|c|c|c|c|c|c|c|}
\hline \multirow[b]{4}{*}{ Source } & \multirow{4}{*}{$\begin{array}{l}\text { Study } \\
\text { collections }\end{array}$} & \multicolumn{15}{|c|}{ Cause of death } \\
\hline & & \multicolumn{9}{|c|}{ Tuberculosis } & \multicolumn{6}{|c|}{ Nontuberculous } \\
\hline & & \multicolumn{3}{|c|}{ Pulmonary } & \multicolumn{3}{|c|}{ Peritoneal } & \multicolumn{3}{|c|}{ Other } & \multicolumn{3}{|c|}{ Pulmonary } & \multicolumn{3}{|c|}{ Other } \\
\hline & & $\mathrm{N}$ & $\mathrm{nbf}$ & $\%$ & $\mathrm{~N}$ & $\mathrm{nbf}$ & $\%$ & $\mathrm{~N}$ & $\mathrm{n} \mathrm{b} \mathrm{f}$ & $\%$ & $\mathrm{~N}$ & $\mathrm{n} \mathrm{bf}$ & $\%$ & $\mathrm{~N}$ & $\mathrm{n} \mathrm{b} \mathrm{f}$ & $\%$ \\
\hline $\begin{array}{l}\text { Kelley and Micozzi } \\
\text { (1984) }\end{array}$ & Hamann-Todd & 352 & 31 & 8.8 & 5 & 0 & & 88 & 8 & 9.1 & 385 & 2 & 0.5 & & & \\
\hline $\begin{array}{l}\text { Roberts et al. } \\
\text { (1994) }\end{array}$ & Terry & 255 & 157 & 61.6 & & & & & & & 230 & 51 & 22.2 & 1,086 & 165 & 15.2 \\
\hline Current study & CISC & 11 & 10 & 90.9 & 1 & 1 & 100 & 6 & 0 & & 7 & 1 & 14.3 & 41 & 1 & 2.4 \\
\hline
\end{tabular}

${ }^{1} \mathrm{n} \mathrm{b} \mathrm{f,} \mathrm{new} \mathrm{bone} \mathrm{formation.}$

TABLE 4. Distribution of new bone formation on ribs in tuberculous individuals studied for each collection by side, rib number, and location

\begin{tabular}{|c|c|c|c|c|c|c|}
\hline \multirow[b]{2}{*}{ Source } & \multirow[b]{2}{*}{$\mathrm{N}$} & \multirow[b]{2}{*}{ Side } & \multirow[b]{2}{*}{ Rib number } & \multicolumn{3}{|c|}{ Location on rib } \\
\hline & & & & Vertebral & Mid & Sternal \\
\hline Kelley and Micozzi (1984) & 39 & Left $>$ right $(2: 1)$ & $4-8$ & \multirow{2}{*}{\multicolumn{3}{|c|}{$\begin{array}{l}\text { Exact location unspecified } \\
\text { More common at vertebral end } \\
\text { but present in all areas of rib }\end{array}$}} \\
\hline Roberts et al. (1994) & 155 & Bilateral & Upper & & & \\
\hline Current study & $10^{1}$ & $\begin{array}{l}4 \text { both } \\
4 \text { left } \\
2 \text { right }\end{array}$ & $\begin{array}{l}2-10 \\
\text { More common from } 4-6\end{array}$ & 40 & 10 & 5 \\
\hline
\end{tabular}

${ }^{1}$ Only pulmonary tuberculosis.

TB was not stated as the cause of death (Roberts et al., 1994).

Despite the difficulty in comparing exact location of new bone on the ribs, Table 4 displays the available data. Concerning laterality, both sides were usually affected in all the skeletal collections and on the side affected by the disease in living people (Eyler et al., 1996). In an ossuary investigated by Pfeiffer (1991), 136 left and 123 right ribs were affected. Only Kelley and Micozzi (1984) reported a predominance of involvement on the left side by a ratio of approximately 2 to 1 . Periosteal reaction was more frequent between ribs 4-8 in the studies of both Kelley and Micozzi (1984) and Roberts et al. (1994). Pfeiffer (1991) detected lesions from ribs $3-10$, occurring on their vertebral ends "continuing anteriorly to varying degrees" (Pfeiffer, 1991, p. 195). In the Coimbra sample, the individuals with rib lesions had ages of death ranging from 17-21, except for one who died at 14 years. In these individuals, the more common and severe lesions were from ribs 4-6. This location seems to agree with the selective location of pulmonary TB in the apical and posterior segments of adult lungs, extending from the superior lobes and the superior portions of the inferior lobes. These areas correspond to the vertebral ends of ribs 3-8. Nevertheless, atypical locations can occur, as Barata et al. (1987) reported in their sample of radiographs from pulmonary TB individuals.

In the Coimbra sample, the most common number of ribs to be affected was four. Kelley and Micozzi (1984) reported involvement of one or more ribs, and Eyler et al. (1996) recorded rib enlargement from 1-8 ribs on the affected side of the thoracic cage.
Periostitis on the ribs also occurred in one individual with a nonpulmonary TB cause of death (Table 3 ). In the person with peritoneal $\mathrm{TB}$, the texture and the lower location on the rib cage may be a clue for distinguishing between this disease and pulmonary TB. Rib lesions were also seen on the individual who died from chronic bronchitis, but they were quite different in texture, porosity, and location from the pulmonary TB individuals.

Few hypotheses can be forwarded to explain this: a misrecorded cause of death may have occurred as this skeleton was that of a pastry-worker who died out of hospital. Another explanation is also a possibility, as the medical literature from the earlier 20th century suggests that many cases of TB were hidden by another pulmonary disease such as chronic bronchitis (Lopo de Carvalho, 1935; Hardy, 1994). Tuberculosis was not a socially accepted disease or cause of death (Hardy, 1994), particularly in North America and England where victims were often hidden away (Bryder, 1996), but this seems not to be the case for Portugal. Nevertheless, perhaps this could explain why, in other countries, mortality due to TB decreased during the 19th century, while in Portugal TB increased from the second half of the 19th century until the 1930 s.

The third case of rib involvement was in a 19-yearold male. The patient file states that he was hospitalized for around 7 months due to osteoarthritis in the right knee and septicemia. This case suggests a similar bone response to a different disease, but a mis- or incomplete diagnosis at the time of admission is also possible. The hospital had different diets for patients depending on their health problems (Campos, 1921; Santos, 1999). This person's diet 
changed during his time in the hospital: before surgery a "normal" diet was given, but post-operatively this changed to a "kidney problems" diet. During almost all the remaining time a so-called S, or "super diet" for the tuberculous, was administered.

\section{CONCLUSIONS}

Despite data linking new bone formation on ribs with pulmonary $\mathrm{TB}$, the scientific community remains cautious about using this feature as a diagnostic criterion for TB because no such correspondence has been reported in living individuals with tuberculosis, apart from suggestions by Eyler et al. (1996). However, current clinical diagnostic criteria may not be appropriate for diagnosis in paleopathology. For example, new bone formation on ribs and periosteal reactions involving the long bones are not described as diagnostic criteria for TB in the medical literature, probably because these changes are invisible on radiographs and are therefore not relevant to diagnosis. Our findings suggest that careful observation and a good description of all bone changes could avoid loss of time and money spent on radiological analyses.

We think that the changes we have noted in this study may be relevant to a diagnosis of TB. Nevertheless, we advise care in the interpretation of the nature and distribution of bone formed on ribs, as these lesions (as seen in this study) seem to be relevant to specific disease processes. In this study, skeletal lesions related to TB largely surpass published figures in the medical literature. We hope to confirm the trends reported here in the near future through an ongoing study in the adults of the CISC. Molecular analysis in some of these individuals is expected to contribute to improved diagnosis and knowledge of TB in past human populations.

\section{ACKNOWLEDGMENTS}

The authors thank the Anthropological Museum at the University of Coimbra for the opportunity to study the Coimbra Identified Skeletal Collection. We thank Carlos Barata for the photographs, Eugénia Cunha from the Department of Anthropology, and also from the Coimbra University Hospital, the technicians Lino Santos and Teresa Rafael for the radiographs. Due acknowledgment is also given to the four reviewers and Emóke Szathmáry whose comments contributed considerably to the final text. This work was developed from presentations at the 12th Meeting of the European Paleopathology Association, Pilsen/Praha (Czech Republic) in 1998, and at the 68th Annual Meeting of American Association of Physical Anthropologists (Columbus, OH) in 1999.

\section{LITERATURE CITED}

Anderson R. 1999. Tuberculose chiffres et polemique. Recherche 319:36-39.

Antunes AF, Antunes ML. 1997. Tuberculose em Portugal, 1995: estatísticas e aspectos epidemiológicos. Lisbon: Direcção Geral Saúde.
Aufderheide A, Rodríguez-Martin C. 1998. The Cambridge encyclopedia of human paleopathology. Cambridge: Cambridge University Press.

Ávila R. 1992. Novas perspectivas na avaliação da imunidade e da hipersensibilidade na tuberculose. Via Pneumol 5:127-130.

Barata F, Arrobas A, Pato R. 1987. Radiologia da tuberculose pulmonar do adulto. Revisão de 100 casos. Jorn Med 123:247249.

Brock TD. 1982. The etiology of tuberculosis by Robert Koch (translation from 1882). Rev Infect Dis 4:1270-1274.

Brown P. 1992. The return of the big killer. New Scientist 10th October; 37:30-37.

Bryder L. 1996. "Not always one and the same thing": the registration of tuberculosis deaths in Britain, 1900-1950. Soc Hist Med 9:253-265.

Buikstra JE. 1999. Paleoepidemiology of tuberculosis in the Americas. In: Pálfi G, Dutour O, Deák J, Hutás I, editors. Tuberculosis: past and present. Budapest-Szeged: TB Foundation and Golden Book Publishers. p 479-494.

Buikstra JE, Ubelaker D, editors. 1994. Standards for data collection from human skeletal remains. Arkansas Archeological Survey Research Seminar Series no. 44. Fayetteville, AR: Arkansas Archeological Survey.

Campos AV. 1921. Projecto de dietas e raçoes para doentes adultos dos Hospitais da Universidade de Coimbra. Univers Coimbra Dir Hosp Bol Hosp Univers 1:1-32.

Clever LH, LeGuyader Y. 1995. Infectious risks for health care workers. Annual Rev Public Health 16:141-164.

Crubézy E, Ludes B, Poveda JD, Clayton J, Crouau-Roy B, Montagnon D. 1998. Identification of Mycobacterium DNA in an Egyptian Pott's disease of 5,400 years old. C R Acad Sci [III] 321:941-951.

Cunha E. 1993. Évolution de la maladie hyperostotique: de Coimbra médiévale a Coimbra de la fin du XIX siécle. Bull Mem Soc Anthropol Paris 5:313-320.

Cunha E. 1994. Paleobiologia das populações medievais Portuguesas-os casos de Fão e S. João da Almedina. Ph.D. thesis. Facculdade de Ciências e Tecnolgia da Universidade de Coimbra.

Cunha E. 1995. Testing identification records: evidence from the Coimbra Identified Skeletal Collections (19th-20th centuries). In: Saunders S, Herring A, editors. Grave reflections. Portraying the past through cemetery studies. Toronto: Canadian Scholars Press. p 179-198.

Cunha E, Gomes P. 1994. As linhas de Harris na Colecção de esqueletos identificados do Departamento de Antropologia da Universidade de Coimbra. Acta Radiol 24:31-36.

Cunha E, Umbelino C. 1995. What can bones tell about labour and occupation: the analysis of skeletal markers of occupation stress in the Identified Skeletal Collection of the Anthropological Museum of the University of Coimbra (preliminary results). Antropol Port 13:47-66.

Cunha E, van Vark G. 1991. The construction of sex discriminant functions from a large collection of skulls of known sex. Int J Anthropol 6:53-66.

Cutileiro J. 1954. Acerca da epidemiologia da tuberculose em Portugal de 1929 a 1948. In: Colêctania de Trabalhos Médicos de Discípulos de Pulido Valente. Lisbon: Livraria Luso-Espanhola, Lda. p 103-194.

Daniel TM. 1997. Captain of death: the story of tuberculosis. New York: University of Rochester Press.

Derry D. 1938. Pott's disease in ancient Egypt. Med Press 197: 196-199.

El-Najjar M. 1981. Skeletal changes in tuberculosis: the Hamann-Todd Collection. In: Buikstra J, editor. Prehistoric tuberculosis in the Americas. Chicago, IL: Northwestern University Archeological Program. p 85-97.

Eyler W, Monsein L, Beute G, Tilley B, Schultz L, Schmitt W. 1996. Rib enlargement in patients with chronic pleural disease. Am J Radiol 167:921-926.

Farer L, Lowell L, Meador M. 1979. Extrapulmonary tuberculosis in the US. Am J Epidemiol 109:205-217.

Formicola V, Milanesi Q, Scarsini C. 1987. Evidence of spinal tuberculosis at the beginning of the fourth millenium $\mathrm{BC}$ from 
Arene Candide Cave (Liguria, Italy). Am J Phys Anthropol 72:1-6.

Gernaey A, Minnikin D, Copley M, Ahmed A, Robertson D, Nolan J, Chamberlain A. 1999. Correlation of the occurrence of mycolic acids with tuberculosis in an archaeological population. In: Pálfi G, Dutour O, Deák J, Hutás I, editors. Tuberculosis: past and present. Budapest-Szeged: TB Foundation and Golden Book Publishers. p 275-282.

Gonçalves-Ferreira FA. 1990. História da saúde e dos serviços de saúde em Portugal. Lisbon: Fundação Calouste Gulbenkian.

Hardy A. 1994. "Death is the cure of all disease": using the general register office cause of death statistics for 1837-1920. Soc Hist Med 7:473-492.

Hopewell P. 1994. Overview of clinical tuberculosis. In: Bloom B, editor. Tuberculosis: pathogenesis, protection, and control. Washington, DC: ASM Press. p 25-46.

Johnston W. 1993. Tuberculosis. In: Kiple K, editor. The Cambridge world history of human diseases. Cambridge: Cambridge University Press. p 1059-1068.

Kelley M, El-Najjar M. 1980. Natural variation and differential diagnosis of skeletal changes in tuberculosis. Am J Phys Anthropol 52:153-167.

Kelley M, Micozzi M. 1984. Rib lesions in chronic pulmonary tuberculosis. Am J Phys Anthropol 65:381-386.

Lopes C, Santos AL, Cunha E. 1999. A possible case of human tuberculosis on a medieval farm in Corroios (Portugal) [abstract]. In: Cockburn E, editor. Paleopathology Association. Papers on paleopathology presented at the 26th Annual Meeting of the Paleopathology Association, Columbus, Ohio. Detroit, MI: $\mathrm{p} 12$.

Lopo de Carvalho F. 1935. A luta contra a tuberculose em Portugal. Jorn Med 11:1-38.

Myers J. 1977. Captain of all these men of death. Tuberculosis historical highlights. St. Louis: Warren H. Green.

Organização Mundial de Saúde. 1989. Classificação das doenças, traumatismos e causas de morte: 9th revisão-1975. Estatísticas de saúde. Lisbon Instituto Nacional de Estatistica. p 12-17.

Ortner D. 1979. Disease and mortality in the Early Bronze Age people of Bad edh-Dhra, Jordan. Am J Phys Anthropol 51:589597.

Pálfi G, Marcsik A, Kovács J. 1992. Lumbosacral and hip tuberculosis in a migration period skeleton. J Paleopathol 4:179184.

Petrie W, Quibell J. 1896. Nagada and Ballas. London: Quaritch.

Pfeiffer S. 1991. Rib lesions and New World tuberculosis. Int J Osteoarchaeol 1:191-198.

Porto J. 1927. A tuberculose em Coimbra no último quarto de século. Biblos 3:154-167, 317-324.

Raviglione M, Snider D, Kochi A. 1995. Global epidemiology of tuberculosis. Morbidity and mortality of a worldwide epidemic. JAMA 273:220-226.

Resnick D, Niwayama G. 1988. Diagnosis of bone and joint disorders. Philadelphia: W.B. Saunders.

Rieder HL, Cauthen GM, Comstock GW, Snider DE Jr. 1989. Epidemiology of tuberculosis in the United States. Epidemiol Rev 11:79-98.

Roberts C. 1999. Rib lesions and tuberculosis: the current state of play. In: Pálfi G, Dutour O, Deák J, Hutás I, editors. Tuberculosis: past and present. Budapest-Szeged: TB Foundation and Golden Book Publishers. p 311-316.

Roberts C, Lucy D, Manchester K. 1994. Inflammatory lesions of ribs: an analysis of the Terry Collection. Am J Phys Anthropol 95:169-182.

Roberts C, Boylston A, Buckley L, Chamberlain A, Murphy EM. 1998. Rib lesions and tuberculosis: the paleopathological evidence. Tubercle Lung Dis 79:55-60.
Rocha MA. 1995. Les collections ostéologiques humaines identifiées du Musée Anthropologique de l'Université de Coimbra. Antropol Port 13:7-38.

Rogers J, Waldron T. 1995. A field guide to joint disease in archaeology. West Sussex: John Wiley \& Sons.

Salo W, Aufderheide A, Buikstra J, Holcomb T. 1994. Identification of Mycobacterium tuberculosis DNA in a pre-Columbian Peruvian mummy. Proc Natl Acad Sci USA 91:2091-2096.

Santos AL. 1995a. Death, sex and nutrition: analysis of the cause of death in the Coimbra human skeleton collection [abstract]. Int J Anthropol 9:235.

Santos AL. 1995b. Death, sex and nutrition: analysis of the cause of death in the Coimbra human skeleton collection. Antropol Port 13:81-91.

Santos AL. 1995c. Certezas e incertezas sobre a idade à morte. Trabalho de síntese das provas de aptidão pedagógica e capacidade científica. Coimbra: Universidade de Coimbra.

Santos AL. 1996. How old is this pelvis? A comparison of age at death estimation using the auricular surface of the ilium and os pubis. In: Pwiti G, Soper R, editors. Aspects of African archaeology. Papers from the 10th Congress of the Pan-African Association for Prehistory and Related Studies. Harare: University of Zimbabwe Publications. p 29-36.

Santos AL. 1999. TB files: new hospital data (1910-1936) on the Coimbra Identified Skeletal Collection. In: Pálfi G, Dutour O, Deák J, Hutás I, editors. Tuberculosis: past and present. Budapest-Szeged: TB Foundation and Golden Book Publishers. p 127-134.

Santos AL, Cunha E. 1997. Some paleopathological aspects from the medieval necropolis of Granja dos Serrões (Portugal). In: López, MM, Sánchez J, editors. La enfermedad en los restos humanos arqueológicos. Cádiz: Universidade de Cádiz Servicio de Publicaciones. p 335-339 and erratum.

Scannell J. 1992. A world of wonders. Harvard Med Alum Bull Summer: $24-25$.

Seymour J. 1992. Fears mount over Britain's TB figures. New Scientist 10th October; 37:34.

Silva AM. 1995. Sex assessment using the calcaneus and talus. Antropol Port 13:107-119.

Spigelman M, Lemma E. 1993. The use of the polymerase chain reaction (PCR) to detect Mycobacterium tuberculosis in ancient skeletons. Int J Osteoarcheol 3:137-143.

Stirland A, Waldron T. 1990. The earliest cases of tuberculosis in Britain. J Archaeol Sci 17:221-230.

Suzuki T. 1985. Paleopathological diagnosis of bone tuberculosis in the lumbosacral region. J Anthropol Soc Nippon 93:381-390.

Taylor M, Crossey M, Saldanha J, Waldron T. 1996. DNA from Mycobacterium tuberculosis identified in mediaeval human skeletal remains using polymerase chain reaction. J Archaeol Sci 23:789-798.

Ulrich-Bochsler S, Schaublin E, Zeltner T, Glowatzki G. 1982. Invalidisierende Wirbelsäulenverkrummung an einem Skelettfund aus dem Frühmittelalter (7./8. bis Anfang 9.Jh.). Schweiz Med Wochenschr 112:1318-1323.

Universidade de Coimbra Direccão dos Hospitais. 1936. Boletim dos Hospitais da Universidade, volume VI. Coimbra: Hopitas da Universidade.

van Rie A, Warren R, Richardson M, Victor TC, Gie RP, Enarson DA, Beyers N, van Helden PD. 1999 Exogenous reinfection as a cause of recurrent tuberculosis after curative treatment. N Engl J Med 341:1174-1179.

Wood JW, Milner G, Harpending HC, Weiss KM. 1992 The osteological paradox. Problems of inferring health from skeletal samples. Current Anthropol 33:343-379.

World Health Organization. 1999. World TB Day. http://www. who.int/gtb/WorldTBDay/ 1999/the_problem.htm. 